\title{
Assessing the thermal performance of a conventional architecture in a dry warm climate
}

\author{
Javier Ascanio Villabonaa ${ }^{1 *}$, Jon Terés Zubiaga ${ }^{2}$, Yesid Alfonso Muñoz Maldonado ${ }^{3}$, Omar Lengerke \\ Pérez ${ }^{1}$, Luis Alfonso Del Portillo Valdés ${ }^{2}$ \\ ${ }^{1}$ College of Natural Sciences and Engineering, Universidad Tecnológicas de Santander, Bucaramanga, Colombia \\ ${ }^{2}$ Energy Engineering Department, University of the Basque Country, Bizkaia, Spain \\ ${ }^{3}$ Energy Engineering Department, Universidad Autonoma de Bucaramanga, Bucaramanga, Colombia
}

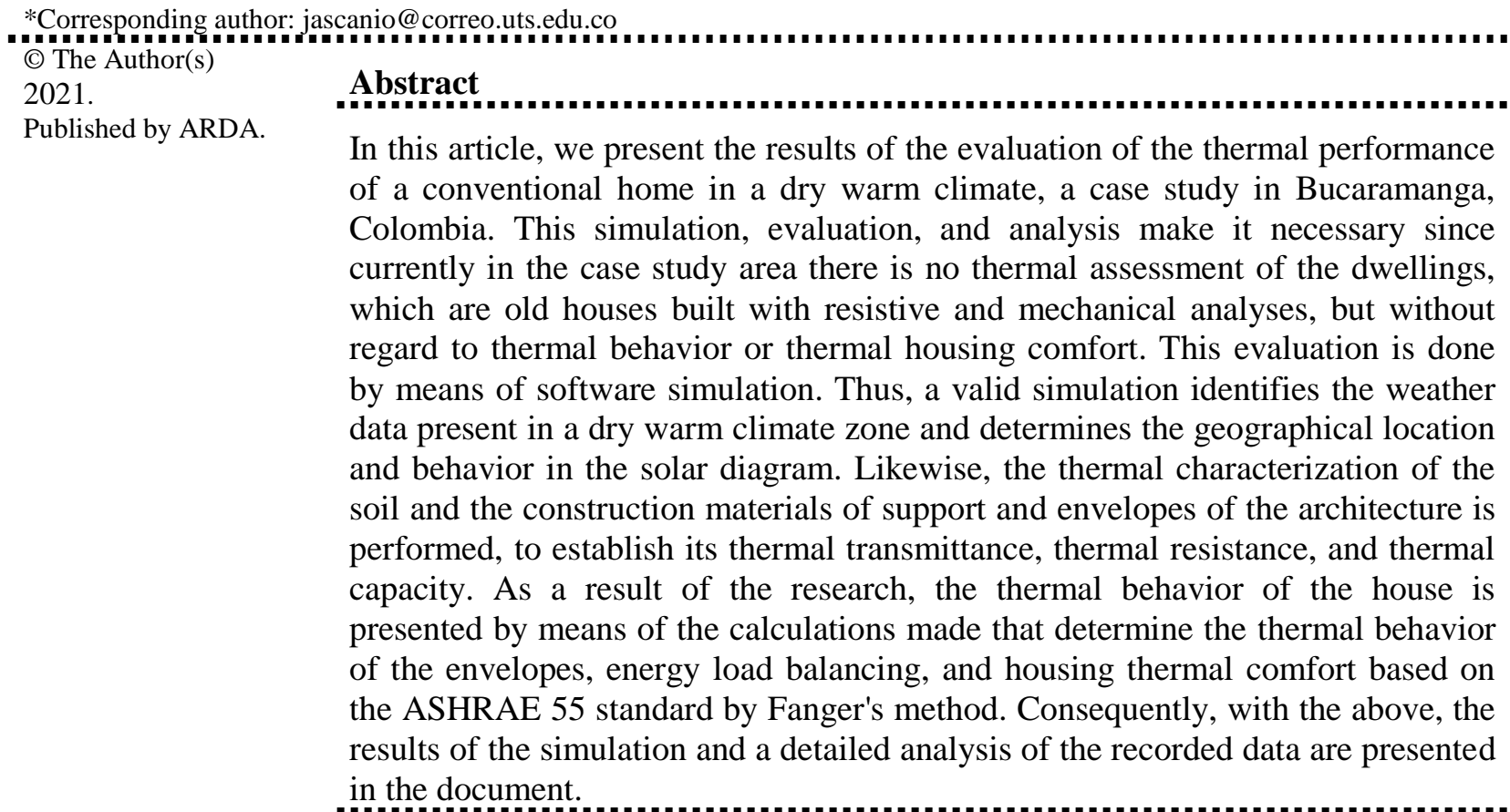

Keywords: Evaluation thermic; Comfort; balance thermic; simulation and transmittance.

\section{Preparation}

Residential and commercial constructions in developed nations account for around $40 \%$ of total energy consumption, outperforming other major sectors such as industry and transportation [1], [2]. In 2019, primary energy use in Colombia's homes accounted for $20 \%$ of the country's total demand [3]. Obviously, the construction sector has a direct impact on society, the environment and the economy [4], [5].

Building design is not only an aesthetic form and concept [6],[7],[8], but also a holistic process that contains an accurate selection of structure materials that can diminish building energy consumption and the implementation of passive design strategies[9], [10], [11]. During their typical natural life of 50 ages or more[12], Contemporary buildings will be subject to a meteorological state that will be progressively hotter and more unstable [13], [14], [15].

From this point of view, it is imperative to understand the energy performance of buildings done precise energy and thermal analysis [16], [17]. The use of unconventional energies, the energy landscape, the likelihood of reviewing Regulations and Building Codes[18], the increase in the purchase of air conditioning

This work is licensed under a Creative Commons Attribution License (https://creativecommons.org/licenses/by/4.0/) that allows others (c) (†) to share and adapt the material for any purpose (even commercially), in any medium with an acknowledgement of the work's authorship and initial publication in this journal. 
equipment, the trend of increase in housing construction, among other causes, motivated different authors to assess residential buildings to examine thermal-energy behavior, comfort situation, energy use [19]-[24].

Therefore, to assess the thermal presentation and energy efficacy of buildings and buildings, numerous simulation programs are used globally that carry out these activities [25]-[28].

The objective of this study is to estimate the thermal behavior of a conventional house case study in dry warm climate, using DesignBuilder software, initiating by the climatic identification of the area [29], followed by the thermal-fisque characterization of soil materials and construction envelopes, in order to analyze according to the ASHRAE 55 standard [30] the parameters of comfort or discomfort present is housing.

\section{Methodology}

A thermal analysis of a case study house was carried out, by means of simulations in the current state of construction. This analysis aimed to determine the current thermal behavior of the case study house, which is a conventional house in dry warm climate, which is located in Bucaramanga, Santander, Colombia. The total area of the house is $126 \mathrm{~m} 2$ and comprises two floors, each is divided into housing spaces of different sizes such as bedrooms, bathrooms kitchen and others.

For the study of the architecture to be evaluated, the method of validation in specialized software that allows the calculation of thermal loads is used [31], because, without a computational tool, the evaluative calculation by the large number of variables to be considered and iterations for its lowest error percentage is not feasible [32].

There are currently a wide diversity of computational tools for the study of thermal loads such as vpClima[33], CYPEcaD MEP[34], OpenStudio[35], Ecotect Software de Sustainable Construction Design[36], Energyplus[37], Designbuilder [38], among others. For this case study the methodology was based on the analysis of thermal-energy performance by simulation using Design Builder software.

\subsection{Identification}

Initially for the base case, the identification of building materials is carried out, with a total area of $126 \mathrm{~m} 2$, comprising two floors. The first floor involves of a breathing room, a kitchen, a bedroom and a bathroom. For the second floor, you have access by stairs starting from the first floor giving way to two bedrooms and a bathroom.

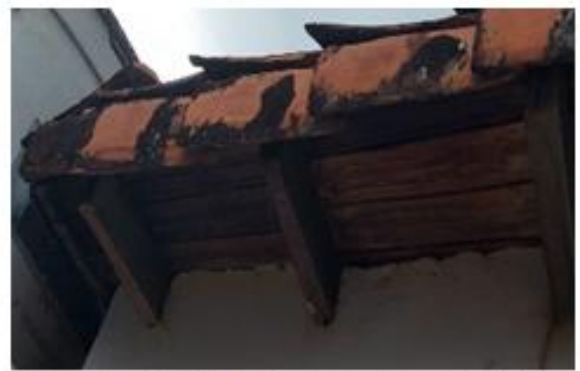

a) Side view of the ceiling beams and wooden laminate supporting mud shingles

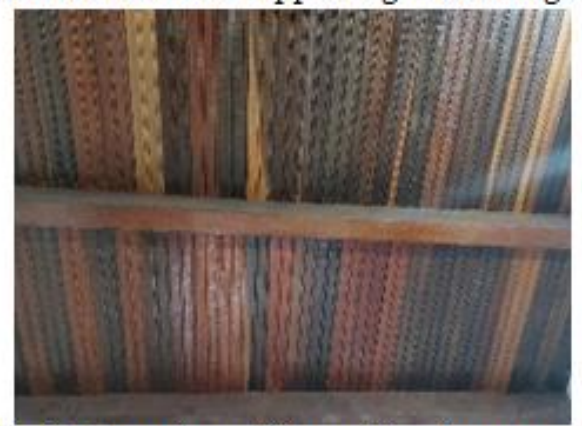

c) Bottom view of the ceiling beams and wooden laminate

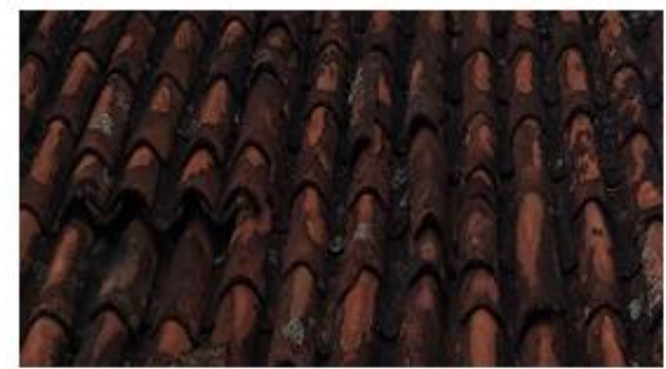

b) Top view of the roof mud shingles medium cane

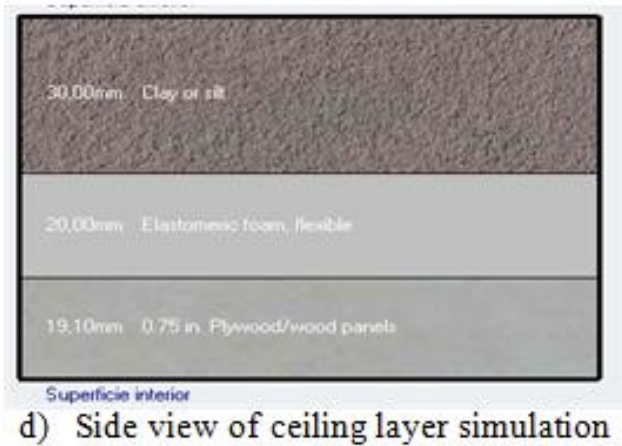

Figure 1. State construction of the current roof of the studio house composed of wood, elastomeric waterproofing enclosure and mud shingles 
The present case study is a construction that used the traditional building material in Colombia as follows: the ceiling is made of wooden beams that support sheets of wood thickness of $1.9 \mathrm{~cm}$, with an elastomeric waterproofing envelope of $2 \mathrm{~cm}$ supporting mud shingles type medium cane with thickness of $3 \mathrm{~cm}$ (see Fig. $1)$.

The floor layers in the area are composed of mixture of sand, gravel and stone, cement biker; $7 \mathrm{~cm}$ cement fiber and ceramic as shown in Fig. 2a. Partition walls include plaster, brick and cement (Fig. 2b). The exterior walls are prefabricated concrete blocks composed of stucco [39], concrete and steel, and the exterior window is made of $6 \mathrm{~mm}$ clear glass. In Table 1mentions the length of the layer conforming to each of the structural envelopes of the house.

Superficie interior

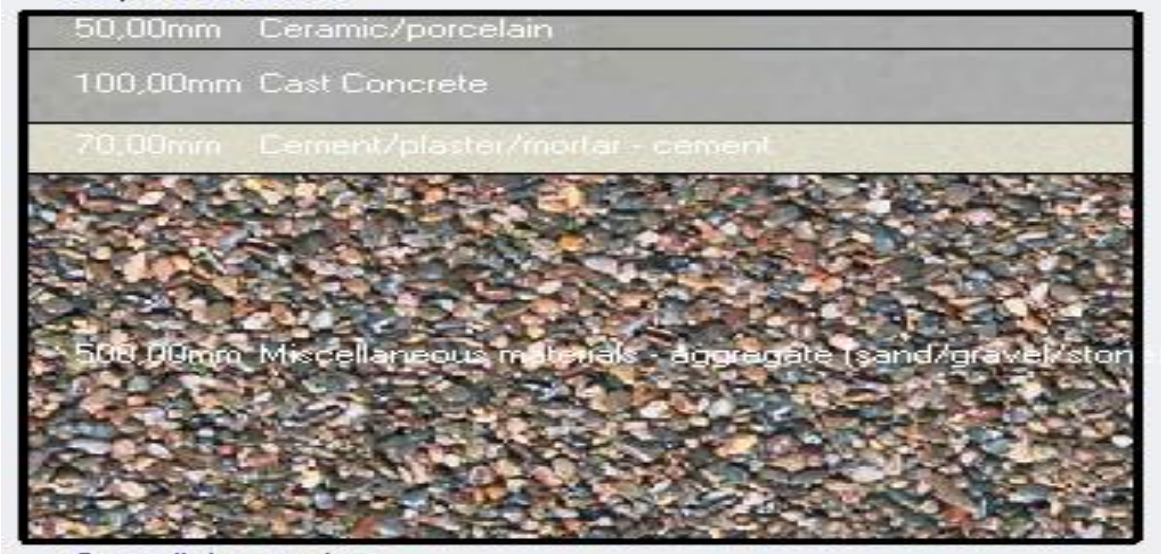

Superficie exterior

a) v ICv LUI1P

Superficie exterior

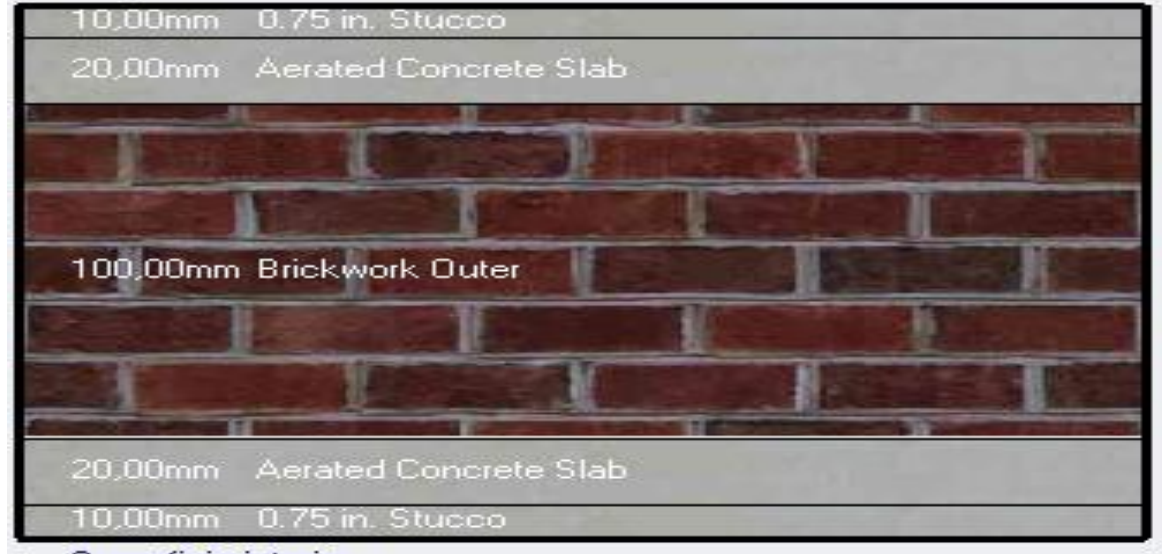

Superficie interior

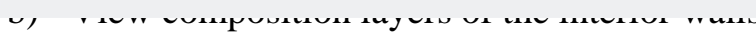

Superficie exterior

\begin{tabular}{|l|}
\hline $20.00 \mathrm{~mm} \quad 0.75$ in. Stuceo \\
\hline $40.00 \mathrm{~mm}$ Aerated Concrete Slab \\
\hline $20.00 \mathrm{~mm} \quad$ Metals - steel \\
\hline $40,00 \mathrm{~mm} \quad$ Aerated Conerete Slab \\
\hline $20.00 \mathrm{~mm} \quad 0.75$ in. Stuceo \\
\hline
\end{tabular}

Superficie interior

c) v IEW compusituon layeis us me vuter walls

Figure 2. Composition of outer and inner envelopes of the case study 
Table 1. Identification of the materials that make up the structure and evolvents of the architecture

\begin{tabular}{|c|c|c|c|c|c|}
\hline \multicolumn{2}{|c|}{ Type of Enclosure } & \multirow{2}{*}{$\begin{array}{l}\text { Outer Walls } \\
\text { stucco }\end{array}$} & \multirow{2}{*}{$\begin{array}{l}\text { Internal Walls } \\
\text { stucco }\end{array}$} & \multirow{2}{*}{$\begin{array}{l}\text { soil } \\
\text { Mixing sand, gravel, stone }\end{array}$} & \multirow{2}{*}{$\begin{array}{l}\text { roof } \\
\text { clay }\end{array}$} \\
\hline clook 1 & Material & & & & \\
\hline Cioan 1 & thickness $(\mathrm{cm})$ & 2 & 1 & 50 & 3 \\
\hline \multirow{2}{*}{ cloak 2} & Material & Concreto & Cement & Cement mortar & $\begin{array}{l}\text { And foam Elastomeric, } \\
\text { flexible }\end{array}$ \\
\hline & thickness $(\mathrm{cm})$ & 4 & 2 & 10 & 2 \\
\hline \multirow{2}{*}{ cloak3 } & Material & iron & brick h10 & Cement board & plywood panels \\
\hline & thickness $(\mathrm{cm})$ & 2 & 10 & 7 & 1,91 \\
\hline \multirow{2}{*}{ cloak 4} & Material & concrete & cement & Ceramica, porcelain & - \\
\hline & thickness $(\mathrm{cm})$ & 4 & 2 & 5 & - \\
\hline \multirow{2}{*}{ cloak 5} & Material & stucco & Stucco & - & - \\
\hline & thickness $(\mathrm{cm})$ & 2 & 1 & - & - \\
\hline
\end{tabular}

\subsection{Simulation}

The architecture is simulated based on the weather data present in dry warm climate and identification of the geographical location in which the case study is located[40] (See Figure 3 in addition to this is the thermal characterization of the enclosures that make up the construction structure of the house as shown in Table 2 .

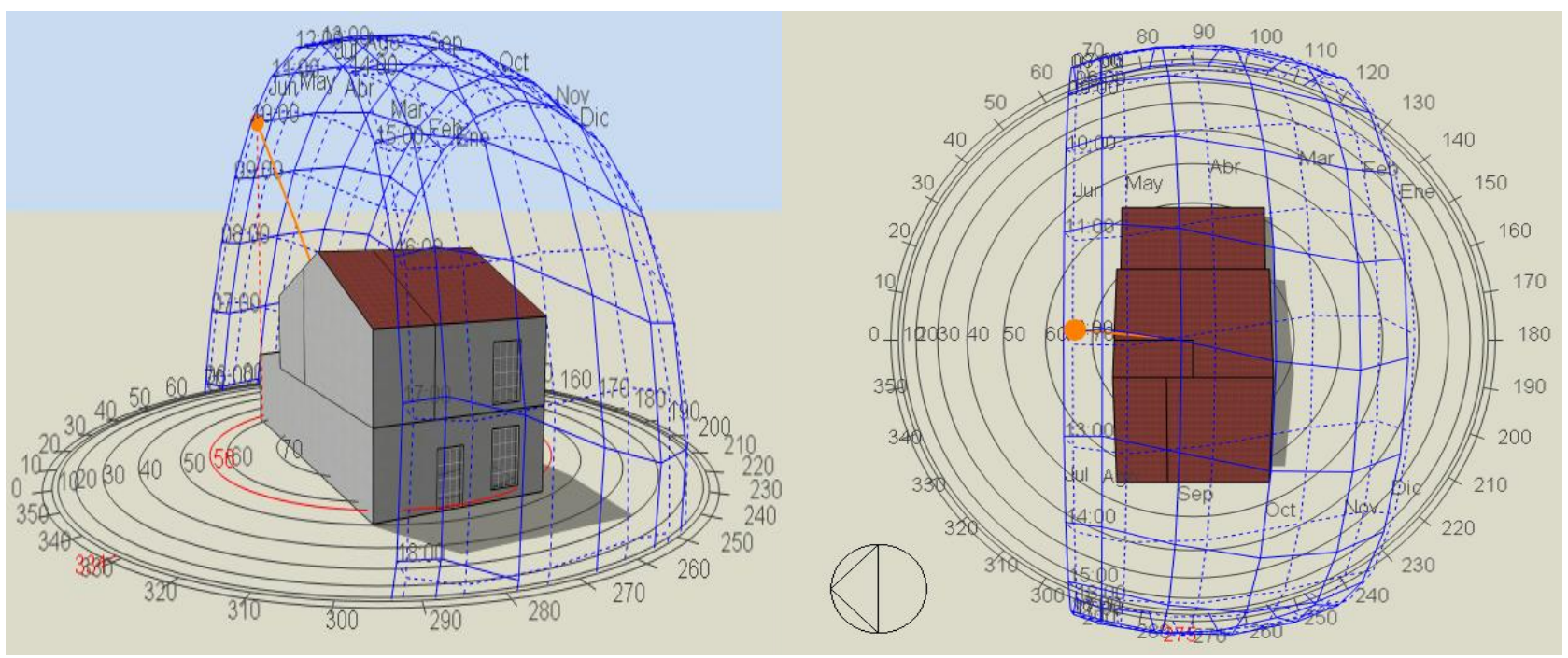

Figure 3. Geographic location and orientation of the case study architecture

Table 2 Thermal characterization of the enclosures of the houses to be studied.

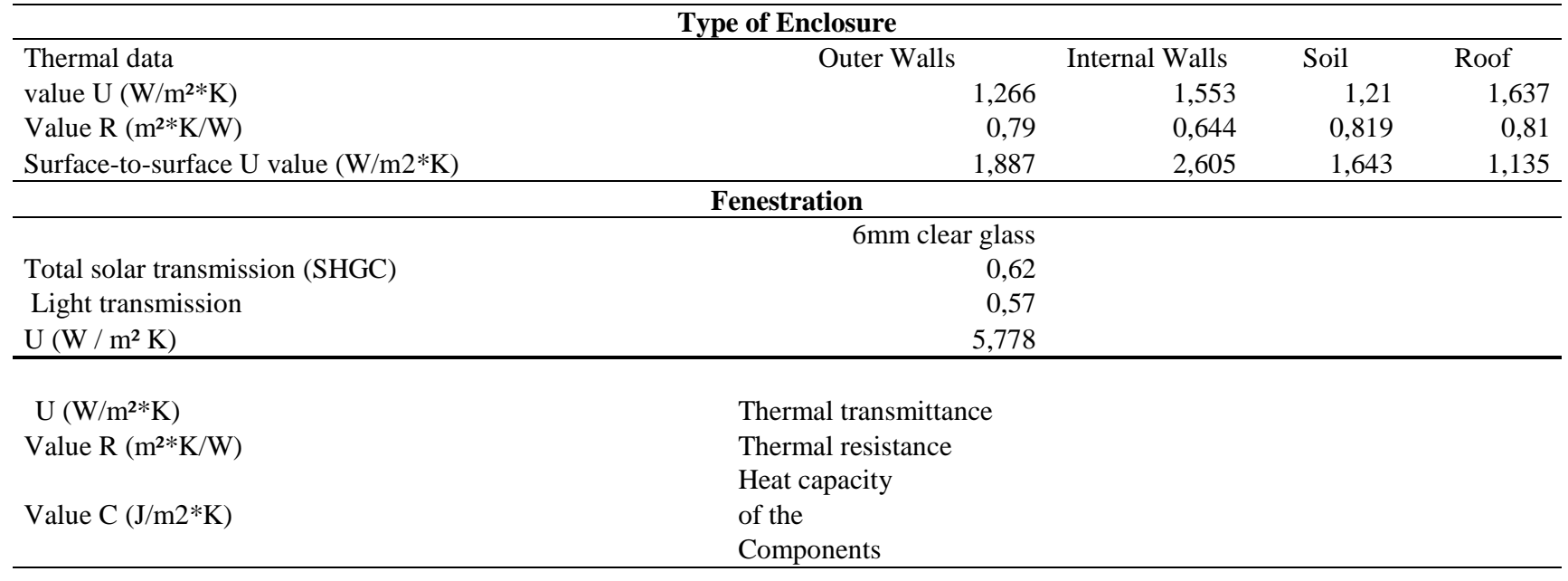


The thermal performance assessment of conventional architecture in dry warm climate is complemented by the analysis of comfort and set point hours completed to determine the housing comfort of the home.

\section{Results}

The interior thermal performance of the house analyzes the thermal-physical properties of structural envelopes such as average climate behavior per hour in a day[41], to determine the internal gains of the case study (See Figure 4).

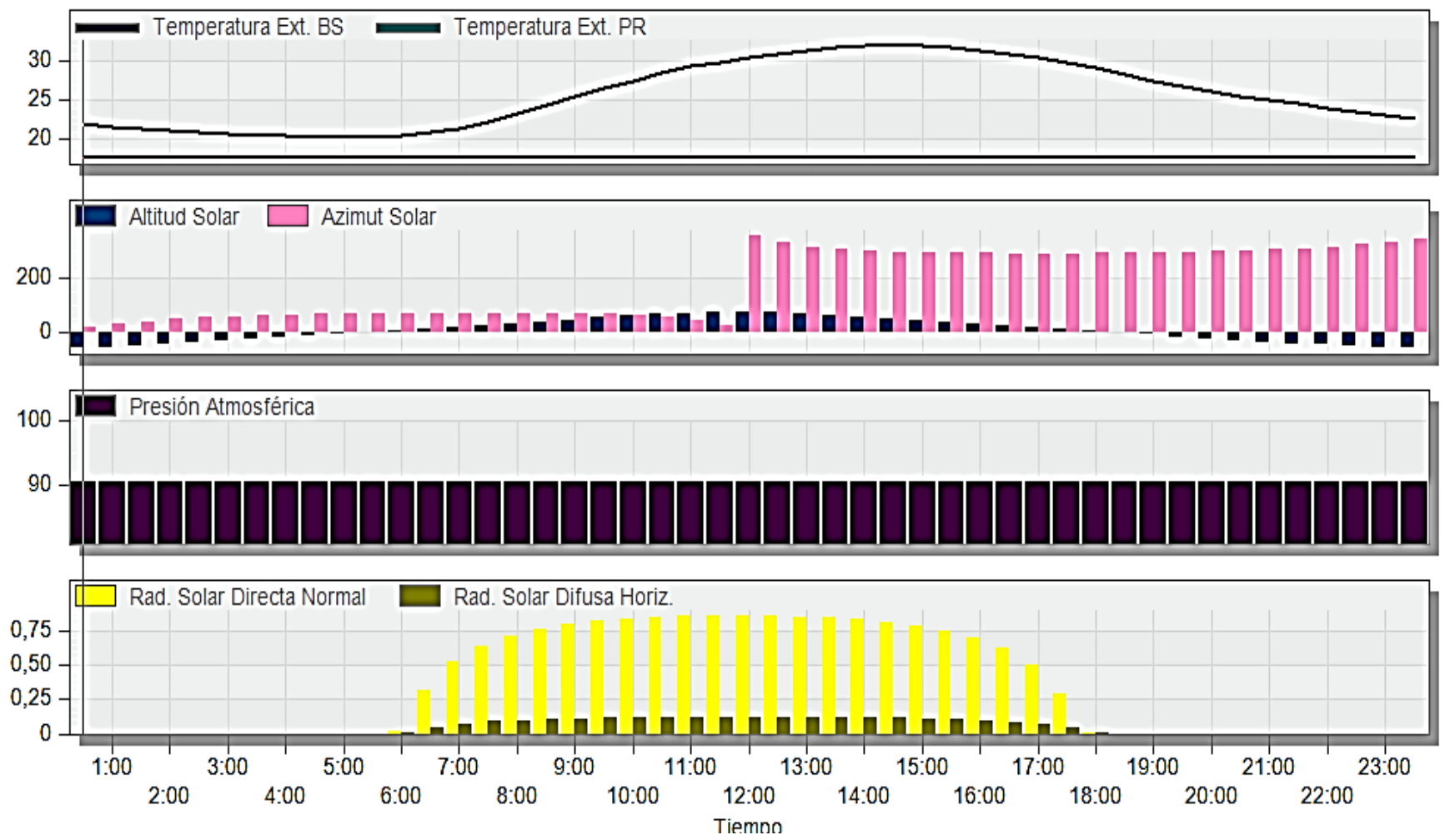

Figure 4. Weather behavior of case study housing

Based on the weather data in which the architecture is exposed, gain data taking into account the thermal balance of the influential factors, the loads of the system such as sensitive cooling and total cooling, ending with the latent load (all this in KW).

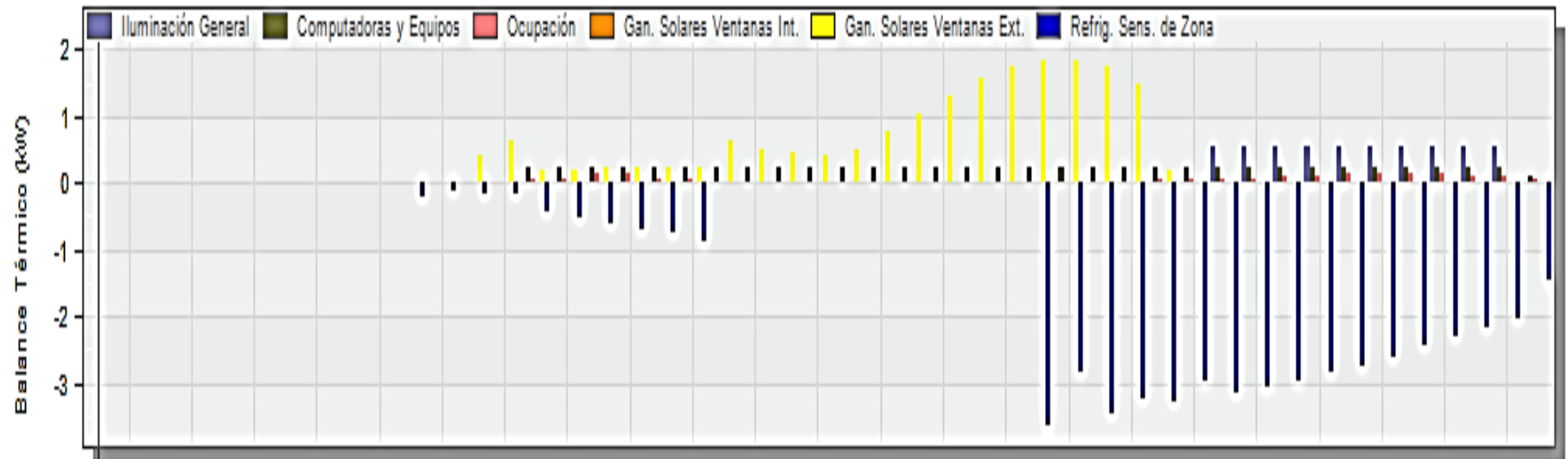

a) Thermal balance 

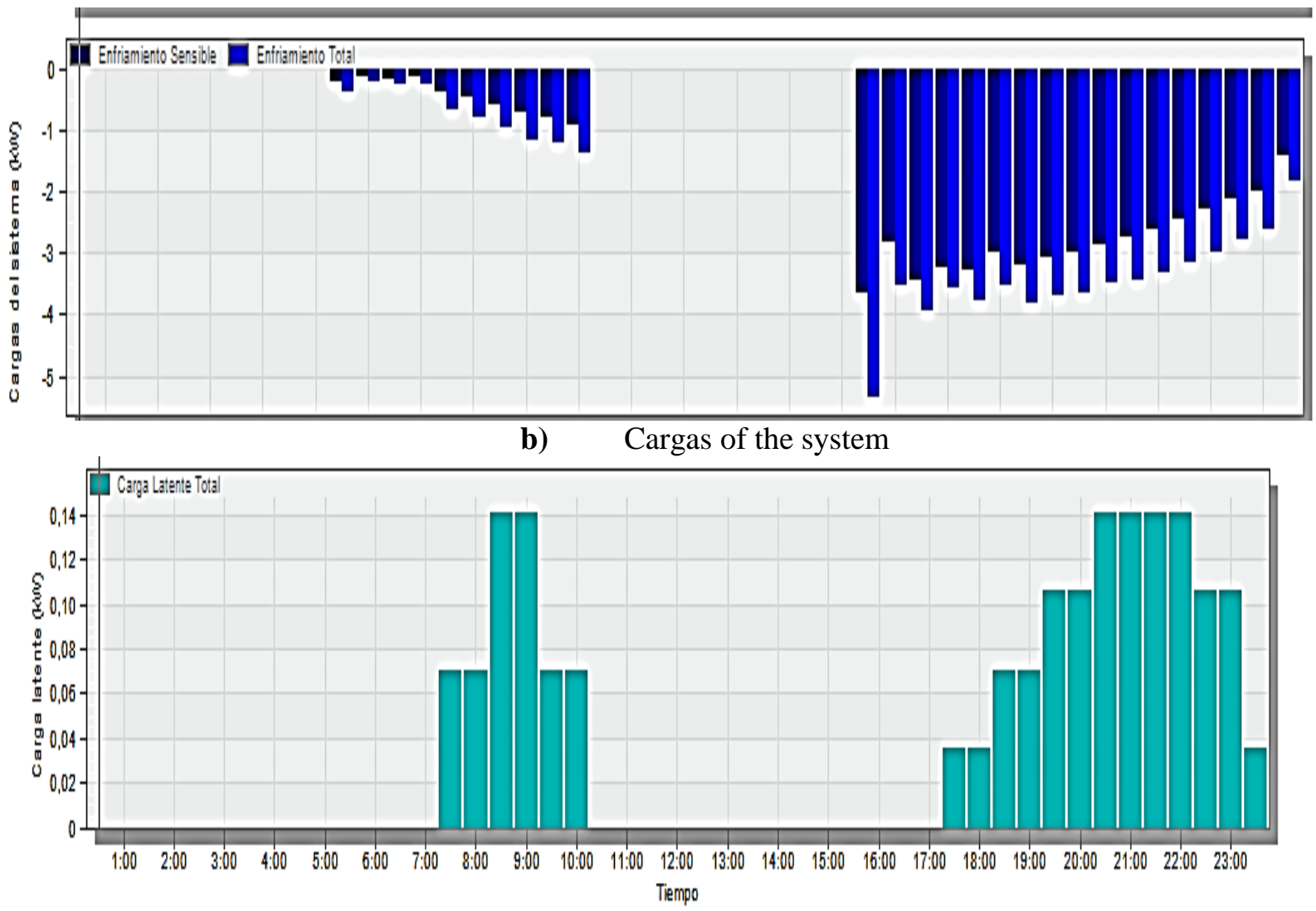

c) Latent charge

Figure 5. Internal thermal gains from architecture

The thermal sensation is modified from person to person in the same area and instantly, so it is thought that even when the expected average vote value (PMV) is neutral, there is a percentage of dissatisfied people. Adding to the above Fanger's method[42], proposes relationship for the evaluation of thermal dissatisfaction called "estimated percentage of dissatisfied" (PPD). The PPD indicates the percentage of people who will eventually feel excessive heat or excessive cold in a given environment[43]. PPD is a function of PMV Figure 6. the function of PPD Vs PMV crossed with the current design condition.

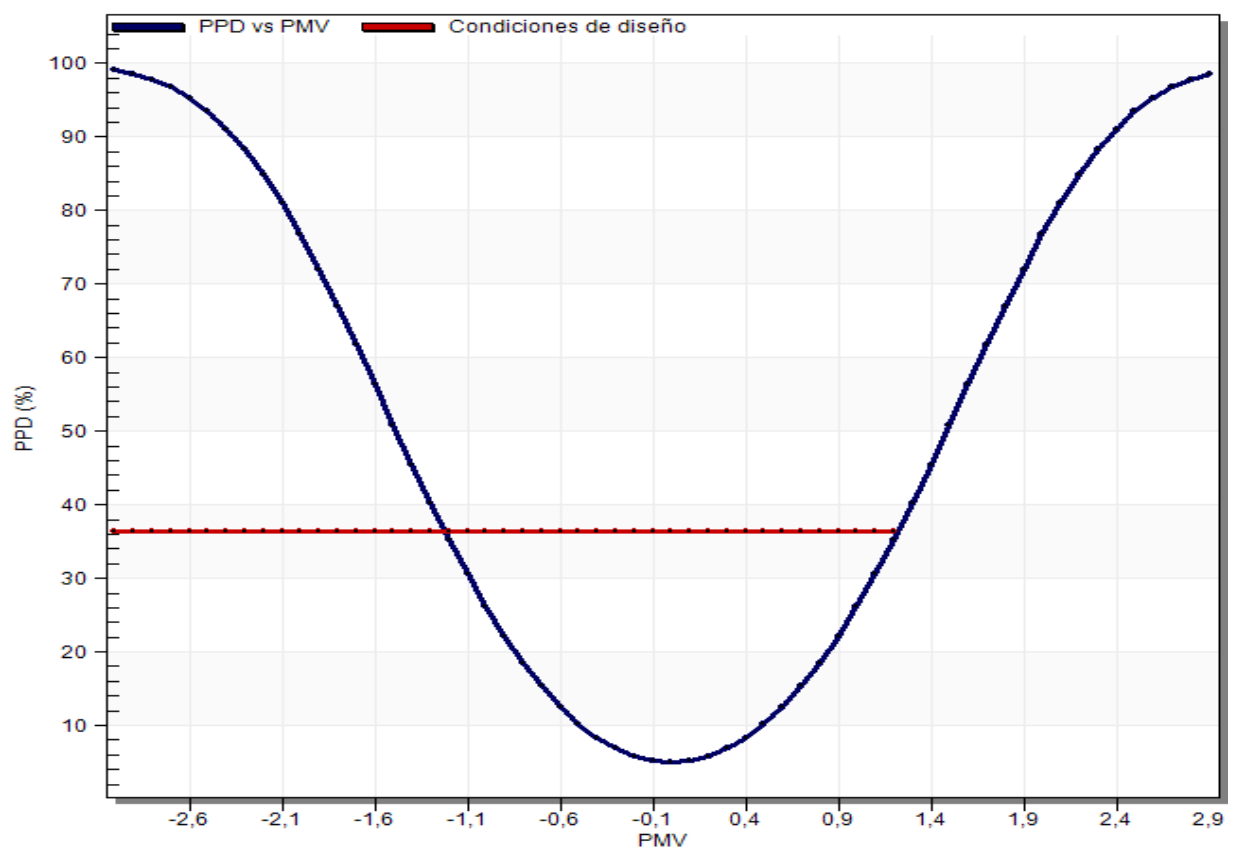

Figure 6. Graph of the thermal comfort of the house case study with the provision of the PPD VS PMV crossed with the design conditions 


\section{Discussion}

The thermal balance has a load gain in KW inside the house, which represents an elevation of temperatures inside it. Consequently, to the above, this thermal gain is presented in large part by the heat transfer obtained between the outside and inside of the enveloping walls by means of transmittance and solar gains (see Figure 7).

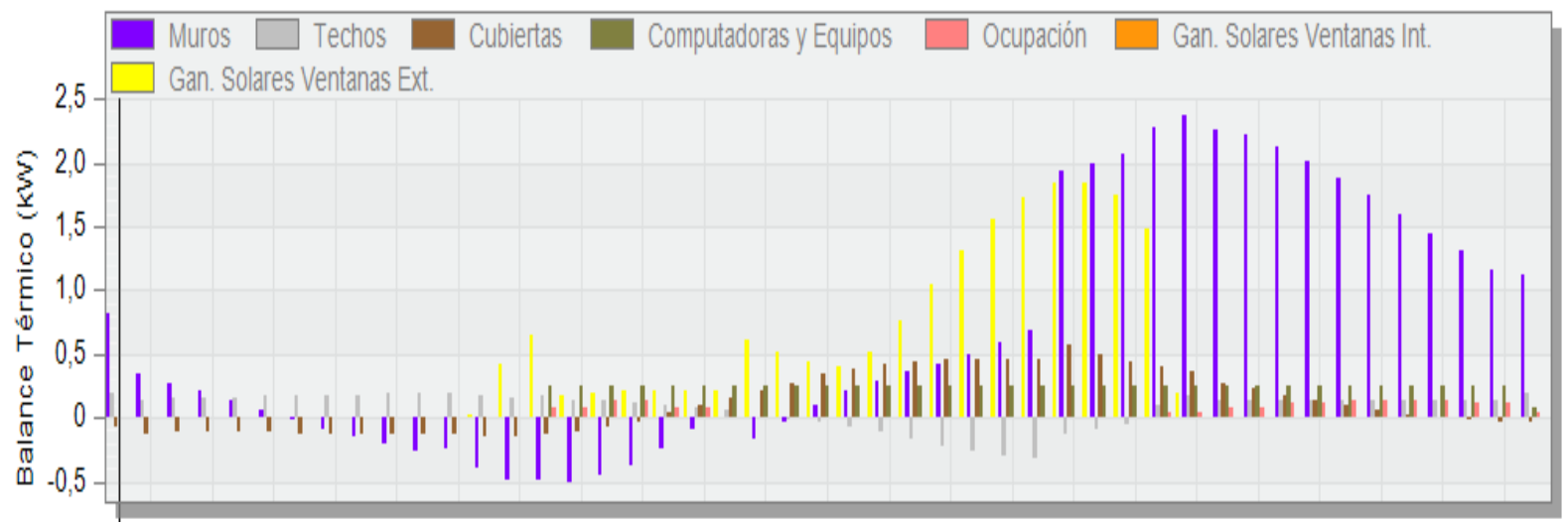

Figure 7. Internal gains plus solar gains in studio architecture

Using PPD Vs PMV[44], [45], rendering to ASHRAE 55[46], establishes that thermal comfort is achieved on the basis of a satisfaction rate of the inhabitants greater than $80 \%$. The excess share of people can feel $10 \%$ body dissatisfaction. To comply with this standard, the recommended thermal frontier at the 7-point PMV level is between -0.5 and 0.5 . PPD can fluctuate between $5 \%$ and $100 \%$, but comfort ranges meets standards, no occupied spots in the area should be above 20\% PPD [46]. Based on this, the housing disconfort is determined in this house, since the PPD is at intersection with the PPD vs PMV function at $36.35 \%$ and the PMV at -1.4 per thermal sensation of heat and 1.1 by the thermal sensation of cold (See Figure 8 . ).

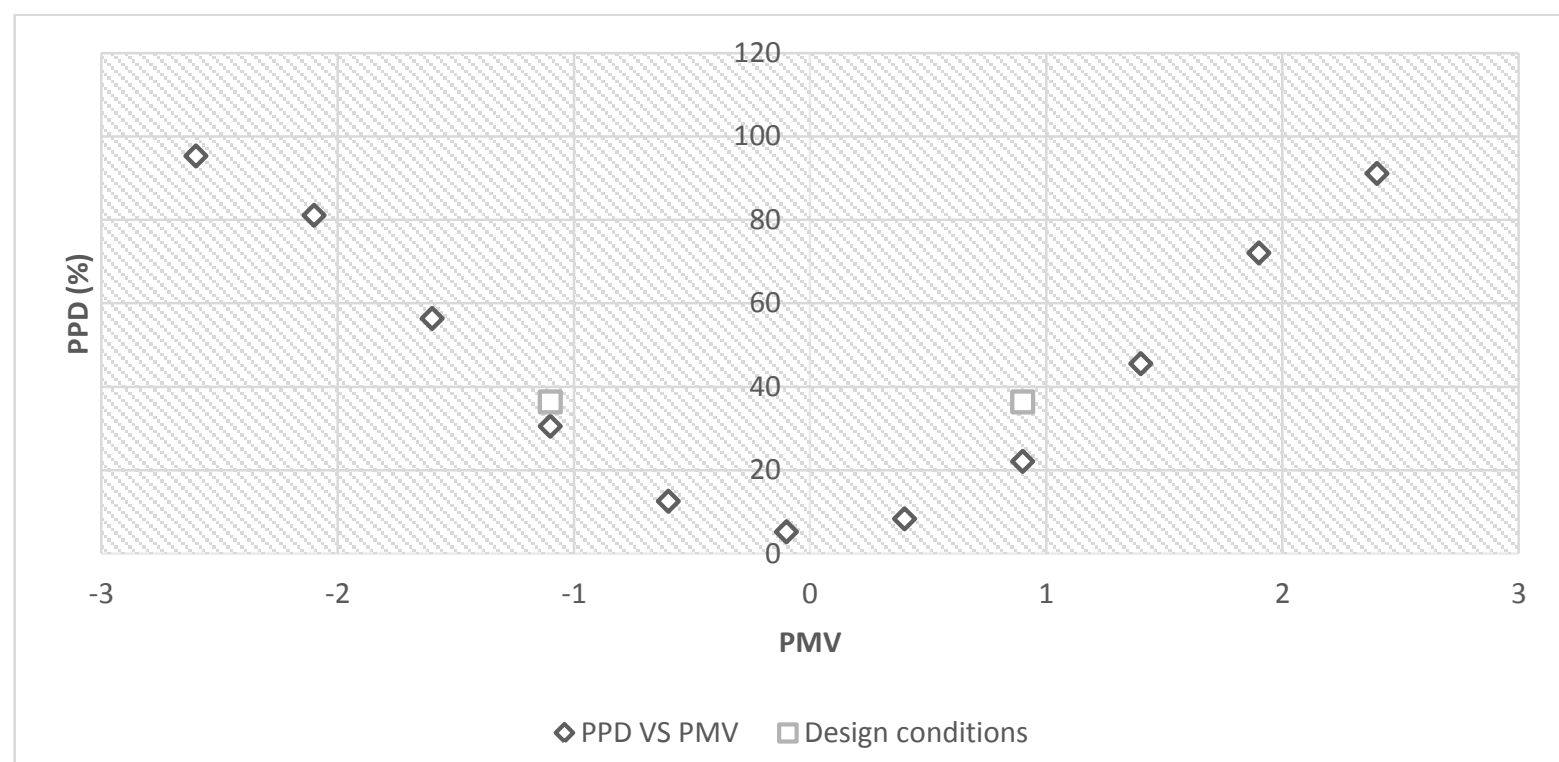

Figure 8. Graph of the intersection points of the PPD Vs PMV function in relation to the design conditions

\section{Conclusion}

It is presented to a conventional townhouse of dry warm climate case study in the city of Bucaramanga, which, is built with common materials of the area thought only of mechanical and structural resistance since this area is a seismic nest of Latin America for its location close to several geological faults[47]-[48]-[49][50]. It is performed characterization of thermal constants such as thermal transmittance, thermal resistance and thermal compactness of the structural components of the case study. 
Subsequent testing takes into account the variables already identified to decrease the error rate in computational tool calculations.

The latent loads if presented is its maximum points when the inhabitants are inside the house, since when analyzing the architecture as a single-family home it is assumed that the people who inhabit it will be only in hours outside of working hours, so some variables oscillate depending on the solar moment and the occupation and activity of equipment.

\section{References}

[1] G. Mustafaraj, D. Marini, A. Costa, and M. Keane, "Model calibration for building energy efficiency simulation," Appl. Energy, vol. 130, pp. 72-85, Oct. 2018, doi: 10.1016/j.apenergy.2014.05.019.

[2] L. Pérez-Lombard, J. Ortiz, and C. Pout, "A review on buildings energy consumption information," Energy Build., vol. 40, no. 3, pp. 394-398, Jan. 2019, doi: 10.1016/j.enbuild.2007.03.007.

[3] UPME, "Plan Energético Nacional 2020-2050," Bogotá D.C, 2019. .

[4] U. Berardi, "Sustainability Assessment in the Construction Sector: Rating Systems and Rated Buildings," Sustain. Dev., vol. 20, no. 6, pp. 411-424, Nov. 2018, doi: 10.1002/sd.532.

[5] S. Mahmoud, T. Zayed, and M. Fahmy, "Development of sustainability assessment tool for existing buildings," Sustain. Cities Soc., vol. 44, pp. 99-119, Jan. 2019, doi: 10.1016/j.scs.2018.09.024.

[6] P. Galarraga, M. Vives, D. Cabrera-Manzano, L. Urda, M. Brito, and V. Gea-Caballero, "The incorporation of community health in the planning and transformation of the urban environment. SESPAS Report 2018," Gaceta Sanitaria, vol. 32. Ediciones Doyma, S.L., pp. 74-81, Oct. 01, 2018, doi: 10.1016/j.gaceta.2018.08.001.

[7] Y. Lu, S. Wang, C. Yan, and Z. Huang, "Robust optimal design of renewable energy system in nearly/net zero energy buildings under uncertainties," Appl. Energy, vol. 187, pp. 62-71, Feb. 2017, doi: 10.1016/j.apenergy.2016.11.042.

[8] E. Zilberberg, P. Trapper, I. A. Meir, and S. Isaac, "The impact of thermal mass and insulation of building structure on energy efficiency," Energy Build., vol. 241, p. 110954, Jun. 2021, doi: 10.1016/j.enbuild.2021.110954.

[9] F. Ascione, M. Borrelli, R. F. De Masi, and G. P. Vanol, "Nearly zero energy target and indoor comfort in Mediterranean climate: Discussion based on monitoring data for a real case study," Sustain. Cities Soc., vol. 61, no. June, p. 102349, 2020, doi: 10.1016/j.scs.2020.102349.

[10] A. S. Dili, M. A. Naseer, and T. Zacharia Varghese, "Passive control methods of Kerala traditional architecture for a comfortable indoor environment: Comparative investigation during various periods of rainy season," Build. Environ., vol. 45, no. 10, pp. 2218-2230, Oct. 2018, doi: 10.1016/j.buildenv.2010.04.002.

[11] M. Fahmy, M. M. Mahdy, and M. Nikolopoulou, "Prediction of future energy consumption reduction using GRC envelope optimization for residential buildings in Egypt," Energy Build., vol. 70, pp. 186193, Feb. 2019, doi: 10.1016/j.enbuild.2013.11.057.

[12] S. Sarihi, F. Mehdizadeh Saradj, and M. Faizi, "A Critical Review of Façade Retrofit Measures for Minimizing Heating and Cooling Demand in Existing Buildings," Sustain. Cities Soc., vol. 64, p. 102525, Jan. 2021, doi: 10.1016/j.scs.2020.102525.

[13] R. Opoku, G. Y. Obeng, J. Darkwa, and S. Kwofie, "Minimizing heat transmission loads and improving energy efficiency of building envelopes in sub-Saharan Africa using bio-based composite materials," Sci. African, vol. 8, p. e00358, Jul. 2020, doi: 10.1016/j.sciaf.2020.e00358.

[14] Y. H. Yau and S. Hasbi, "A review of climate change impacts on commercial buildings and their technical services in the tropics," Renewable and Sustainable Energy Reviews, vol. 18. Pergamon, pp. 430-441, Feb. 2018, doi: 10.1016/j.rser.2012.10.035.

[15] P. de Wilde and D. Coley, "The implications of a changing climate for buildings," Building and Environment, vol. 55. Pergamon, pp. 1-7, Sep. 2017, doi: 10.1016/j.buildenv.2012.03.014.

[16] A. I. Palmero-Marrero, F. Gomes, J. Sousa, and A. C. Oliveira, "Energetic analysis of a thermal building using geothermal and solar energy sources," Energy Reports, vol. 6, pp. 201-206, Dec. 2020, doi: 10.1016/j.egyr.2020.11.268. 
[17] L. Evangelisti, C. Guattari, F. Asdrubali, and R. de Lieto Vollaro, "In situ thermal characterization of existing buildings aiming at NZEB standard: A methodological approach," Dev. Built Environ., vol. 2, no. March, p. 100008, 2020, doi: 10.1016/j.dibe.2020.100008.

[18] M. Shakouri, H. Ghadamian, and A. Noorpoor, "Quasi-dynamic energy performance analysis of building integrated photovoltaic thermal double skin façade for middle eastern climate case," Appl. Therm. Eng., vol. 179, p. 115724, Oct. 2020, doi: 10.1016/j.applthermaleng.2020.115724.

[19] J. A. Picott Basto, "Metodología para el análisis termo-energético de edificios familiares en Colombia con base en las normativa. Tesis de maestría ," 2018.

[20] P. M. G. Re and I. B. Lucas, "MONITOREO HIGROTÉRMICO-ENERGÉTICO-LUMÍNICO DE INVIERNO EN DEPARTAMENTOS UBICADOS EN LAS CIUDADES DE SAN JUAN Y LA PLATA," 2017.

[21] L. E. Fonseca Granados, "Análisis del comportamiento térmico de las envolventes de las viviendas VIS en la ciudad de Tunja desde el enfoque de las tecnologías limpias," Build. Environ., Oct. 2019, doi: 10.1016/j.buildenv.2017.05.019.

[22] J. Andrey and C. Cañas, "EVALUACIÓN DEL CONFORT TÉRMICO EN LA VIVIENDA RURAL EXISTENTE EN COLOMBIA," Universidad La Gran Colombia, 2020.

[23] E. Soto-Estrada, M. F. Alvarez-Carrascal, J. Gomez-Lizarazo, and D. Valencia-Montoya, "Confort térmico en viviendas de Medellín," Rev. Ing. Univ. Medellín, vol. 18, no. 35, pp. 51-68, May 2016, doi: 10.22395/rium.v18n35a4.

[24] L. Marcela, G. Garcia, A. Osorio Saraz, R. Osorio Hernandez, and J. Carlo, "SIMULACIÓN TERMO ENERGÉTICA DE VIVIENDA RURAL CON 4 TIPOS DE PLACAS PREFABRICADAS EN FERROCEMENTO,” 2016.

[25] A. Cacabelos, P. Eguía, L. Febrero, and E. Granada, "Development of a new multi-stage building energy model calibration methodology and validation in a public library," Energy Build., vol. 146, pp. 182-199, 2017, doi: 10.1016/j.enbuild.2017.04.071.

[26] R. Bruno, N. Arcuri, and C. Carpino, "Study of innovative solutions of the building envelope for passive houses in Mediterranean areas," Energy Procedia, vol. 140, pp. 80-92, 2017, doi: 10.1016/j.egypro.2017.11.125.

[27] A. Magrini and G. Lentini, "NZEB analyses by means of dynamic simulation and experimental monitoring in mediterranean climate," Energies, vol. 13, no. 18, 2020, doi: 10.3390/en13184784.

[28] M. Hagenau and M. Jradi, "Dynamic modeling and performance evaluation of building envelope enhanced with phase change material under Danish conditions," J. Energy Storage, vol. 30, no. April, p. 101536, 2020, doi: 10.1016/j.est.2020.101536.

[29] Y. Yang, H. Wu, L. Yang, T. Xu, Y. Ding, and P. Fu, "Thermal and day-lighting performance of aerogel glazing system in large atrium building under cooling-dominant climates," in Energy Procedia, Feb. 2019, vol. 158, pp. 6347-6357, doi: 10.1016/j.egypro.2019.01.273.

[30] “Ashrae,” 2020. https://spain-ashrae.org/ashrae/ (accessed Apr. 06, 2021).

[31] P. Shen, W. Braham, and Y. Yi, "Development of a lightweight building simulation tool using simplified zone thermal coupling for fast parametric study," Appl. Energy, vol. 223, pp. 188-214, Aug. 2018, doi: 10.1016/j.apenergy.2018.04.039.

[32] P. Condoleo and A. Taliercio, "Identifying fault-inducing phenomena in an old masonry building," in Procedia Structural Integrity, Jan. 2018, vol. 11, pp. 290-297, doi: 10.1016/j.prostr.2018.11.038.

[33] U. P. de Valencia, "vpCLIMA,” 2020. http://vpclima2.ter.upv.es/?lang=es (accessed Apr. 11, 2021).

[34] Z. Lozano Martín, C. Afranio, and V. Salgado, "Diseño de un sistema de climatización y ACS basado en fuentes renovables para $2000 \mathrm{~m} 2$ de aulas ubicadas en 6 unidades de un instituto de educación secundaria en Vinaròs (Castellón)," Universitat Politècnica de València, Jul. 2020. Accessed: Apr. 11, 2021. [Online]. Available: https://riunet.upv.es/handle/10251/148617.

[35] Openstudio, "OpenStudio | OpenStudio," 2021. https://www.openstudio.net/ (accessed Apr. 11, 2021).

[36] Ecotect, "Ecotect: Software de Diseño de Construcción Sustentable | ArchDaily Colombia," 2021. https://www.archdaily.co/co/02-62481/ecotect-software-de-diseno-de-construccion-sustentable (accessed Apr. 11, 2021).

[37] EnergyPlus, "EnergyPlus,” 2021. https://energyplus.net/ (accessed Apr. 11, 2021).

[38] Designbuilder, "DesignBuilder Software Ltd - For Architects," 2021. https://designbuilder.co.uk/software/for-architects (accessed Apr. 11, 2021).

[39] S. Navaratnam et al., "Development of cross laminated timber-cold-formed steel composite beam for 
floor system to sustainable modular building construction," Structures, vol. 32, pp. 681-690, Aug. 2021, doi: 10.1016/j.istruc.2021.03.051.

[40] M. S. Geraldi and E. Ghisi, "Building-level and stock-level in contrast: A literature review of the energy performance of buildings during the operational stage," Energy and Buildings, vol. 211. Elsevier Ltd, p. 109810, Mar. 15, 2020, doi: 10.1016/j.enbuild.2020.109810.

[41] Y. Li, B. Y. Lattimer, and S. W. Case, "Measurement and modelling of thermal and physical properties of wood construction materials," Constr. Build. Mater., vol. 284, p. 122780, May 2021, doi: 10.1016/j.conbuildmat.2021.122780.

[42] J. A. Diego-Mas, "Evaluación Del Confort Térmico Con El Método De Fanger," Universidad Politécnica de Valencia, 2015. https://www.ergonautas.upv.es/metodos/fanger/fanger-ayuda.php (accessed Apr. 14, 2021).

[43] “UNE-EN ISO 7730:2006 Ergonomía del ambiente térmico. Determina..." https://www.aenor.com/normas-y-libros/buscador-de-normas/une/?c=N0037517 (accessed Apr. 14, 2021).

[44] T. Cheung, S. Schiavon, T. Parkinson, P. Li, and G. Brager, "Analysis of the accuracy on PMV - PPD model using the ASHRAE Global Thermal Comfort Database II," Build. Environ., vol. 153, pp. 205217, Apr. 2019, doi: 10.1016/j.buildenv.2019.01.055.

[45] X. Jia, B. Cao, Y. Zhu, and B. Liu, "Thermal comfort in mixed-mode buildings: A field study in Tianjin, China," Build. Environ., vol. 185, p. 107244, Nov. 2020, doi: 10.1016/j.buildenv.2020.107244.

[46] ASHRAE, “Estándar ASHRAE 55," 2021. https://www.seiscubos.com/conocimiento/estandar-ashrae55 (accessed Apr. 06, 2021).

[47] Corporación Autónoma Regional para la Defensa de la Meseta de Bucaramanga - CDMB y la Universidad de Santander - UDES., “¿Por qué tiembla con tanta frecuencia en Santander? - UDES Bucaramanga," 2020.

[48] CMGRD Alcaldía de Bucaramanga, "Municipio de Bucaramanga (Santander) Plan Municipal de Gestión del Riesgo de Desastre CMGRD de Bu," 2013.

[49] IDEAM, "CARÁCTERÍSTICAS CLIMATOLÓGICAS DE CIUDADES PRINCIPALES Y MUNICIPIOS TURÍSTICOS,” 2018. Accessed: Apr. 06, 2021. [Online]. Available: http://www.ideam.gov.co/documents/21021/418894/Características+de+Ciudades+Principales+y+Mun icipios+Turísticos.pdf/c3ca90c8-1072-434a-a235-91baee8c73fc.

[50] F. Herrera, "Correlación de eventos sísmicos con la temperatura ambiental, en el área metropolitana de bucaramanga," Bucaramanga, 2013. 